\title{
ANALISIS PERBANDINGAN BEA PEROLEHAN HAK ATAS TANAH DAN BANGUNAN PERUMAHAN GRIYA PANIKI INDAH MANADO BERDASARKAN NILAI JUAL OBJEK PAJAK DAN PETAZONA NILAI TANAH
}

\author{
Muhammad Rangga \\ O. Esry H. Laoh \\ Margaretha Ratulangi
}

\begin{abstract}
The purpose of this research is (1) to compare tax revenue of BPHTB based on NJOP with ZNT Map. (2) to know the potential of revenue that can be improved based on ZNT Map. This research was conducted at Griya Paniki Indah Housing, Kecamatan Mapanget, Manado City. from July to October 2017. The study used a statistical analysis of the mean difference test. The data used in this study is secondary data in the form of price of land and building transactions that occurred in 2014 and 2015. Research results indicate that the amount of revenue BPHTB refers to NJOP PBB or transaction price on 300 samples at Griya Paniki Indah Housing is $R p$. 1,200,274,450, while the amount of BPHTB receipts referring to ZNT Map is Rp. 1,630,663,000 in comparison between NJOP versus ZNT is 1: 1.36. To this difference, the potential for BPHTB increase based on ZNT Map in Griya Paniki Indah Housing is 35.86\%, so that Land Value Zone Map can increase the amount of BPHTB Manado City revenue.
\end{abstract}

Keywords: comparative analysis, acquisition cost, land and building, Griya Paniki Indah residence, Kecamatan Mapanget, Manado City

\section{ABSTRAK}

Tujuan dari penelitian ini adalah (1) membandingkan penerimaan pajak BPHTB yang didasarkan pada NJOP dengan Peta ZNT. (2) untuk mengetahui potensi penerimaan yang dapat ditingkatkan berdasarkan Peta ZNT. Penelitian ini dilaksanakan di Perumahan Griya Paniki Indah, Kecamatan Mapanget, Kota Manado. dari bulan Juli sampai bulan Oktober 2017. Penelitian menggunakan analisis statistik uji beda rata-rata. Data yang digunakan dalam penelitian ini yaitu data sekunder berupa harga transaksi bidang tanah dan bangunan yang terjadi pada tahun 2014 dan 2015. Hasil Penelitian menunjukkan bahwa jumlah penerimaan BPHTB yang mengacu pada NJOP PBB atau harga transaksi pada 300 sampel pada Perumahan Griya Paniki Indah yaitu sebesar Rp. 1.200.274.450, sedangkan jumlah penerimaan BPHTB yang mengacu pada Peta ZNT sebesar Rp. 1.630.663.000 dengan perbandingan antara NJOP berbanding ZNT adalah 1 : 1,36. Terhadap perbedaan tersebut, maka potensi peningkatan BPHTB berdasarkan Peta ZNT pada Perumahan Griya Paniki Indah adalah sebesar 35,86\%, sehingga Peta Zona Nilai Tanah dapat meningkatkan jumlah penerimaan BPHTB Kota Manado.

Kata kunci: analisis perbandingan, bea perolehan, tanah dan bangunan, Perumahan Griya Paniki Indah, Kecamatan Mapanget, Kota Manado 


\section{PENDAHULUAN}

\section{Latar Belakang}

Pembangunan di suatu daerah bertujuan untuk membangun masyarakat seutuhnya, untuk itu diharapkan pembangunan tersebut tidak hanya mengejar kemajuan daerah saja, melainkan mencakup seluruh aspek kehidupan masyarakat, agar dapat berjalan serasi dan seimbang di segala bidang dalam rangka menciptakan masyarakat adil dan makmur yang merata materil dan spitual. Pembangunan derah merupakan kegiatan utama pemerintahan daerah, karena itu rencana pembangunan daerah membutuhkan partisipasi seluruh unsur pemerintah daerah yang ada di daerah tersebut, dan didukung oleh masyarakatnya. Dengan pembangunan daerah yang serasi dan terpadu disertai perencanaan pembangunan yang baik, efisien dan efektif maka akan tercipta kemandirian daerah dan kemajuan yang merata diseluruh wilayah. Hal ini akan membuat Pendapatan Asli Daerah (PAD) meningkat.

Pendapatan Asli Daerah bersumber dari pajak daerah, retribusi daerah, hasil pengelolaan kekayaan daerah yang dipisahkan dan lain-lain pendapatan daerah yang sah. Dalam rangka menjalankan fungsi dan wewenang pemerintah daerah dalam bentuk pelaksanaan kewenangan fiskal, daerah harus dapat mengenali potensi dan mengidentifikasi sumber-sumber daya yang dimilikinya. Pemerintah daerah diharapkan diharapkan mampu menggali sumber-sumber keuangan guna untuk memenuhi PAD. Dalam rangka meningkatkan akuntabilitas dan keleluasaan dalam membelanjakan Anggaran Pendapatan Belanja Daerah (APBD), sumbersumber penerimaan daerah yang potensial harus digali secara maksimal dalam koridor peraturan yang berlaku, termasuk diantaranya pajak daerah.

Pendapatan Asli Daerah (PAD) dapat dipandang sebagai salah satu indikator untuk mengukur tingkat ketergantungan suatu daerah kepada pemerintah pusat. Kemampuan suatu daerah dapat dilihat dari besar kecilnya PAD yang di peroleh suatu daerah. Pada prinsipnya, semakin besar sumbangan PAD pada APBN maka semakin kecil tingkat ketergantungan daerah kepada pemerintah pusat. Terbitnya Undang-undang Nomor 28 Tahun 2009 tentang Pajak Daerah dan Retribusi Daerah berimplikasi pada semakin menguatkan pemerintah daerah dalam mengolah pajak dan retribusi daerah. Berdasarkan regulasi ini daerah berhak menggunakan pungutan kepada masyarakat dan menempatkan perpajakan sebagai salah satu sumber pendapatan daerah. Pajak Bumi dan Bangunan (PBB) dan Bea Perolehan Hak atas Tanah dan Bangunan (BPHTB) adalah pendapatan dari sektor pajak yang sangat potensial bagi daerah. Pengelolaan PBB oleh daerah harus sudah dilakukan selambat-lambatnya pada tahun 2013 dan per 1 Januari 2011 Pemerintah Daerah Kota Manado mengeluarkan Peraturan daerahh Kota Manado Nomor 1 tahun 2011 sebagai landasan dalam pemungutan Bea Perolehan Hak atas tanah dan bangunan (BPHTB) telah diserahkan KPP Pratama kepada Pemerintah Kota Manado. Dengan adanya pengalihan ini, BPHTB di percaya sebagai sumber pendapatan asli daerah yang memiliki potensi sangat besar.

Nilai Jual Objek Pajak (NJOP) selama ini digunakan sebagai dasar dalam pengenaan PBB. Proses penentuan NJOP haruslah sesuai dengan ketentuan Nilai Pasar Wajar (NPW), jadi pemerintah tidak salah jika berharap bahwa NJOP adalah sama dengan nilai pasar. Tetapi kenyataannya NJOP seringkali tidak sesuai dengan NPW, hal ini mendasari semakin berkembangnya sistem penilaian harga pasar menggunakan Peta Zona Nilai Tanah (ZNT). Peta ZNT adalah peta yang menggambarkan suatu zona geografis yang terdiri atas sekelompok objek pajak yang mempunyai satu Nilai Indikasi Ratarata (NIR) yang dibatasi oleh batas penguasaan atau pemilikan objek pajak dalam satu wilayah administrasi desa atau kelurahan. Pembuatan peta ZNT memerlukan data berupa harga tanah yang berdasarkan nilai pasar sebagai informasi tekstualnya.

Menurut Sutaryono (2013), Hubungan Zona Nilai Tanah dengan Penerimaan Negara antara lain :

a. BPN RI : Sebagai dasar perhitungan tarif PNBP (Penerimaan Negara Bukan Pajak) dalam permohonan, perpanjangan, pembaruan, atau peralihan hak atas tanah

b. Pemerintah Daerah : Sebagai informasi, dasar perhitungan maupun second opinion NJOP PBB dan BPHTB.

c. Instansi yang memerlukan tanah : Sebagai referensi dalam perencanaan anggaran dan penetapan nilai ganti rugi dalam pengadaan tanah untuk kepentingan umum.

d. PPAT (Pejabat Pembuat Akta Tanah) : sebagai dasar perhitungan biaya dan pajak yang terkait dengan pembuatan akta. 
e. Publik : Sebagai referensi masyarakat dalam transaksi pertanahan dan properti.

Harga NJOP yang telah ditentukan oleh pemerintah biasanya didasarkan pada survey yang telah dilakukan sebelumnya. Tetapi fakta yang terjadi di lapangan, harga NJOP yang ditetapkan oleh pemerintah tersebut jauh lebih rendah jika dibandingkan dengan harga aktual di pasaran. Hal ini salah satunya juga dipengaruhi oleh perilaku masyarakat yang cenderung menurunkan harga objek pajak miliknya sehingga beban pajak yang harus dibayarkannya juga berkurang atau lebih rendah. Padahal hal ini sangat berpengaruh terhadap pemasukan pajak daerah. Semakin rendah harga NJOP, maka semakin rendah pula pendapatan pajak suatu daerah. Bahkan, akibat perbedaan yang begitu drastis antara NJOP dengan harga riil di lapangan. Kementrian Agraria dan Tata Ruang mengusulkan penghapusan PBB dan NJOP diganti dengan sistem Zona Nilai Tanah. Menteri Agraria yakin dengan adanya sistem zonasi ini maka akan mengurangi spekulasi terhadap harga tanah dan juga otomatis akan menyederhanakan administrasi.

Pembangunan perumahan di Kota Manado khususnya Perumahan Griya Paniki Indah yang merupakan perumahan terbesar di Sulawesi Utara memunculkan banyaknya objekobjek pajak yang baru, sehingga potensi pemasukan pajak daerah dari perumahan ini sangat tinggi bagi Kota Manado. Permasalahan timbul ketika seseorang melakukan transaksi jual beli terhadap suatu bidang tanah di perumahan tersebut, banyak ditemukan bahwa nilai transaksi jual beli yang dicantumkan pada Akta Jual Beli yang dibuat oleh PPAT tidak sesuai dengan harga pasar yang wajar dengan alasan mengacu pada nilai tanah yang tertera pada NJOP PBB. Hal ini dikarenakan pembeli ingin terhindar dari pajak BPHTB yang tinggi, yang pada akhirnya penerimaan pajak BPHTB yang merupakan penerimaan daerah menjadi berkurang, Permasalahan lain yang timbul adalah penggunaan nilai transaksi yang digunakan sebagai dasar perhitungan BPHTB. Ketentuan tentang dasar yang digunakan sebagai dasar perhitungan BPHTB baik yang diatur dalam Undang-Undang BPHTB maupun dalam UndangUndang Pajak Daerah dan Retribusi Daerah adalah dengan menggunakan nilai transaksi. Nilai transaksi adalah nilai yang merupakan kesepakatan antara para pihak yang melakukan transaksi, seperti kalau dalam jual beli adalah antara penjual dengan pembeli, sehingga kepastian hukum nilai transaksi turut dalam menentukan sah tidaknya sebuah jual beli, dalam hal ini apakah benar bahwa nilai transaksi baik yang dicantumkan dalam akta jual beli maupun yang digunakan sebagai dasar perhitungan BPHTB adalah benar-benar sesuai dengan kenyataan yang telah disetujui atau disepakati oleh pihak-pihak yang melakukan transaksi. Alasannya adalah jika Nilai Perolehan Objek Pajak tidak diketahui atau lebih rendah daripada NJOP yang digunakan dalam pengenaan Pajak Bumi dan Bangunan pada tahun terjadinya perolehan, dasar pengenaan yang dipakai adalah NJOP Pajak Bumi dan Bangunan, sedangkan NJOP Pajak Bumi dan Bangunan pada saat ini belum mencerminkan harga tanah yang sebenarnya dan terkadang jauh dibawah harga pasaran.

Adanya penggunaan nilai transaksi sebagai dasar perhitungan BPHTB inilah yang sering kali menimbulkan permasalahan di lapangan, karena tidak jarang nilai transaksi yang diajukan oleh wajib pajak dianggap tidak sesuai oleh petugas pajak, sehingga tidak jarang petugas pajak dalam proses verifikasi/validasi, meminta agar nilai transaksi diubah dan disesuaikan menurut penilaian petugas pajak. Hal ini dapat terjadi karena merupakan suatu hal yang wajar, bahwa pada umumnya orang berkeinginan agar membayar pajaknya ringan, sehingga nilai yang dicantumkan dalam akta dan yang digunakan sebagai dasar perhitungan BPHTB tidak sesuai dengan kenyataan yang sebenarnya yang telah disetujui oleh pihak-pihak. Demikian juga sebaliknya, petugas pajak menginginkan pajak yang dibayar dapat maksimal. Penggunaan nilai transaksi sesuai dengan harga pasar cenderung jauh lebih tinggi dari Nilai Jual Obyek Pajak Bumi dan Bangungan (NJOP PBB), sehingga petugas pajak dalam menentukan nilai transaksi yang sebenarnya tidaklah mudah, dalam melakukan penelitian atas kebenaran nilai transaksi yang dipakai wajib pajak untuk menghitung BPHTB, petugas dinas harus mencari data dan keterangan ataupun informasi dari berbagai pihak, yang sebenarnya tidak mudah untuk memperoleh nilai yang pasti dan menjamin kebenaran. Bahkan tidak menutup kemungkinan nilai transaksi yang ditentukan oleh petugas pajak ini justru tidak sesuai dengan kenyataan yang sebenarnya, hal inilah yang menjadi masalah karena tidak adanya kepastian mengenai nilai transaksi. 
Pada dasarnya nilai transaksi dalam sebuah jual beli ditentukan semata oleh para pihak sendiri berdasarkan kesepakatan, dan tidak ada satu pihak manapun yang dapat menentukan, apalagi memaksa untuk menggunakan nilai tertentu. Dalam hal terjadi pemaksaan atau suatu tindakan yang mengakibatkan nilai transaksi tidak sesuai dengan kenyataan yang telah disepakati oleh pihak-pihak, maka transaksinya dapat menjadi tidak sah dan batal. Dari gambaran tersebut, maka nilai transaksi baik yang diajukan oleh wajib pajak yang dimuat dalam akta dan sebagai dasar perhitungan BPHTB dengan nilai transaksi menurut penilaian petugas pajak dalam proses validasi adalah bersifat relatif dan subyektif, sehingga dapat menimbulkan ketidakpastian. Ketidakpastian ini dapat menimbulkan berbagai konsekuensi hukum, antara lain, dapat mengakibatkan transaksinya menjadi tidak sah dan menjadi batal, bahkan dapat merugikan masyarakat, karena harus membayar pajak yang lebih tinggi dari yang seharusnya. Di samping itu, juga menimbulkan prosedur yang rumit dan panjang, karena diperlukan proses validasi yang kadang memakan waktu yang rumit dan lama. Berdasarkan hal tersebut, maka perlu dikaji secara mendalam mengenai nilai yang tepat dan pasti sebagai dasar penghitungan pengenaan BPHTB yang harus dibayar oleh masyarakat yang melakukan peralihan hak atas tanah. Permasalahan yang dapat timbul selain itu adalah bahwa harga tanah yang ditetapkan mendasarkan pada Nilai Jual Objek Pajak (NJOP) untuk PBB. Menurut Sutaryono (2013), kondisi di lapangan menunjukkan bahwa harga tanah berdasarkan NJOP hanya berkisar 20-40\% dari harga pasar. Artinya harga tanah yang didasarkan pada NJOP jauh lebih kecil dari pada harga pasar. Kondisi ini menguntungkan pemilik tanah dalam hal kewajiban pajak, karena pajaknya menjadi kecil. Pada kondisi yang berbeda, pemilik tanah merasa dirugikan apabila NJOP dijadikan dasar dalam pemberian ganti rugi. Solusinya untuk mendapatkan harga tanah yang relatif lebih fair, dapat digunakan nilai yang terdapat dalam Zona Nilai Tanah (ZNT) produk BPN. ZNT ini dimaknai sebagai area yang menggambarkan nilai tanah yang relatif sama dari sekumpulan bidang tanah di dalamnya, yang batasannya bersifat imajiner ataupun nyata sesuai dengan penggunaan tanah dan mempunyai perbedaan nilai antara satu dengan yang lainnya berdasarkan analisis perbandingan harga pasar dan biaya. Mengingat ZNT berbasis nilai pasar, maka ZNT dapat dimanfaatkan untuk :

a. penentuan tarif dalam pelayanan pertanahan

b. referensi masyarakat dalam transaksi

c. penentuan ganti rugi

d. inventori nilai asset publik maupun aset masyarakat

e. monitoring nilai tanah dan pasar tanah

f. referensi penetapan NJOP untuk PBB, agar lebih adil dan transparan.

Penelitian ini bertujuan untuk membandingkan harga tanah berdasarkan NJOP dan berdasarkan harga pasar sehingga dapat diketahui potensi pemasukan pajak daerah dengan menggunakan Peta Zona Nilai Tanah sebagai instrumen penilaian harga pasar.

\section{Rumusan Masalah}

Secara garis besar, permasalahan yang akan diuraikan lebih lanjut adalah sebagai berikut

1. Bagaimana perbandingan pajak BPHTB yang didasarkan pada Nilai Jual Objek Pajak dengan Peta Zona Nilai Tanah?

2. Bagaimana persentase peningkatan potensi penerimaan Pendapatan Asli Daerah khususnya BPHTB yang dapat digali berdasarkan pada Peta Zona Nilai Tanah di Perumahan Griya Paniki Indah?

\section{Tujuan Penelitian}

Tujuan penelitian ini antara lain:

1. Menganalisis perbandingan penerimaan pajak BPHTB sebagai salah satu sumber pendapatan daerah yang didasarkan pada NJOP dengan Peta Zona Nilai Tanah.

2. Menganalisis potensi peningkatan penerimaan pajak BPHTB dari Perumahan Griya Paniki Indah berdasarkan pada Peta Zona Nilai Tanah bagi Pemerintah Kota Manado.

\section{Manfaat Penelitian}

Manfaat dari penelitian ini adalah

1. Secara praktis penelitian ini dapat dijadikan bahan referensi bagi Pemerintah Daerah dalam pengambilan kebijakan, dapat diketahui besarnya potensi penerimaan pajak dari BPHTB sebagai salah satu sumber Pendapatan Asli Daerah dari sektor pajak.

2. Secara teoritis penelitian ini dapat digunakan sebagai referensi untuk penelitian sejenis, baik metodologi, studi pustaka dan analisa. 


\section{METODOLOGI PENELITIAN}

\section{Lokasi dan Waktu Penelitian}

Penelitian ini dilaksanakan di Perumahan Griya Paniki Indah, Kecamatan Mapanget, Kota Manado. Waktu pelaksanaan penelitian yaitu selama 3 (tiga) bulan, terhitung sejak bulan Juli sampai dengan bulan Oktober 2017.

Peneliti mengambil lokasi penelitian di Perumahan Griya Paniki Indah karena perumahan merupakan jenis properti yang paling dominan dan paling sering ditransaksikan. Perumahan Griya Paniki Indah adalah perumahan yang telah mengikuti Peraturan Pemerintah Nomor 14 Tahun 2016 tentang Penyelenggaraan Perumahan dan Kawasan Pemukiman. Peraturan tersebut mempertegas kewajiban pengusaha untuk memenuhi hunian berimbang agar membangun rumah menengah dan rumah sederhana jika membangun rumah mewah dengan pola 1:2:3. Hunian berimbang dengan pola 1:2:3 berarti bagi pengembang yang membangun satu unit rumah mewah, harus membangun dua unit rumah menengah, serta tiga unit rumah sederhana. Perumahan ini adalah perumahan terbesar di Sulawesi Utara dan telah dibangun 6000 rumah yang di dalamnya terdapat beragam hunian mulai dari rumah sederhana, rumah menengah, hingga rumah yang tergolong mewah, sehingga diharapkan melalui penelitian di perumahan ini hasilnya dapat merepresentasikan Kota Manado secara keseluruhan.

\section{Metode Pengumpulan Data}

Sugiyono (2010:16) menyatakan bahwa pengumpulan data dapat menggunakan dua sumber yaitu sumber primer dan sumber sekunder. Sumber sekunder merupakan sumber yang tidak langsung memberikan data kepada pengumpul data. Data yang diperoleh atau dikumpulkan dari sumber-sumber yang telah ada. Data sekunder diperoleh dari bukti-bukti tertulis maupun informasi lain berupa literatur-literatur yang berkaitan dengan penelitian.

Data yang digunakan dalam penelitian ini yaitu data sekunder berupa data penerimaan Pendapatan Asli Daerah dari Sektor Bea Perolehan Hak Atas Tanah dan Bangunan dari tahun 2011 sampai dengan 2016 Kota Manado. Data lain yang dikumpulkan adalah data nilai transaksi jual beli, Nilai Jual Objek Pajak PBB, Bea Perolehan Hak Atas Tanah dan Bangunan atas transaksi bidang tanah yang terletak di Perumahan Griya Paniki Indah.
Penelitian dilakukan dengan mengambil 300 sampel secara merata pada Perumahan Griya Paniki Indah dan kemudian distratifikasi menjadi golongan rumah sederhana, rumah menengah, dan rumah mewah. Peneliti menggolongkan rumah sederhana sebanyak 150 sampel, rumah menengah sebanyak 100 sampel, dan rumah mewah sebanyak 50 sampel. Data-data sekunder diperoleh dari badan atau instansi yang terkait, seperti Kantor Pertanahan Kota Manado, Badan Pengelola Pajak dan Retribusi Daerah Kota Manado, Badan Pusat Statistik, Developer Perumahan Griya Paniki Indah, maupun Internet.

\section{Variabel Penelitian}

Variable-variabel yang digunakan dalam penelitian ini merupakan data sekunder yang terdiri dari :

1. Alamat rumah atau bidang tanah, untuk mengetahui stratifikasi bidang tanah dalam pengambilan sampel.

2. Luas bidang tanah, adalah acuan dalam menentukan besarnya BPHTB yang akan dikalikan dengan harga tanah.

3. Luas atau tipe bangunan, untuk mengetahui besarnya bangunan sehingga mendapatkan harga bangunan secara keseluruhan.

4. Harga Bangunan, untuk mengetahui dan mendapatkan nilai tanah per meter persegi dengan cara nilai tanah dikurangi oleh nilai atau harga bangunan.

5. Harga Transaksi, dengan melihat harga yang tertera di dalam Akta Jual Beli yang dibuat oleh Notaris/PPAT yang dilakukan oleh penjual dan pembeli .

6. Bea Perolehan Hak Atas Tanah dan Bangunan (BPHTB), adalah hasil perhitungan dari harga yang ditransaksikan.

7. Nilai Tanah pada Peta Zona Nilai Tanah, adalah nilai yang tercantum pada Peta Zona Nilai Tanah di dalam perumahan Griya Paniki Indah.

\section{Metode Analisis Data}

\section{Analisis Deskriptif.}

Metode deskriptif adalah suatu metode analisis yang mengumpulkan, menyusun, mengelolah dan menganalisis data yang digunakan guna memperoleh suatu kesimpulan. Teknik analisis data yang digunakan dalam penelitian ini adalah analisis deskriptif untuk menjabarkan tentang analisis pengenaan BPHTB. 


\section{Analisis Inferensial (Uji beda rata-rata)}

Uji hipotesis uji beda rata-rata digunakan untuk mengetahui ada atau tidak adanya perbedaan (kesamaan) antara dua buah data. Salah satu teknik analisis statistik untuk menguji hipotesis beda rata-rata ini ialah uji $\mathrm{t}(\mathrm{t}$ test) karena rumus yang digunakan disebut rumus $t$.

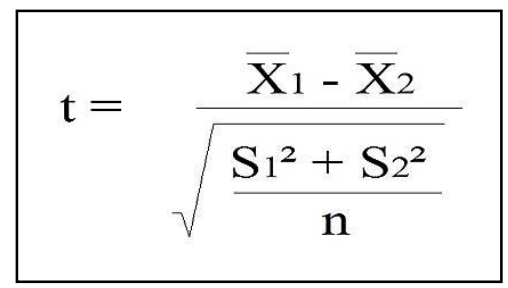

Keterangan :

$\mathrm{X}_{1}$ adalah rata-rata jumlah BPHTB berdasarkan Peta ZNT

$\mathrm{X}_{2}$ adalah rata-rata jumlah BPHTB berdasarkan NJOP

$\mathrm{S}_{1}^{2}$ adalah varians data jumlah BPHTB berdasarkan Peta ZNT.

$\mathrm{S}_{2}{ }^{2}$ adalah varians jumlah BPHTB berdasarkan NJOP.

$\mathrm{n}$ adalah jumlah sampel pada Perumahan Griya Paniki Indah.

\section{HASIL DAN PEMBAHASAN}

\section{Gambaran Umum Wilayah Penelitian}

Pertumbuhan penduduk yang pesat ditambah masuknya para pendatang di Kota Manado menyebabkan meningkatnya permintaan akan hunian khususnya perumahan. Bahwa yang menjadi pertumbuhan perumahan di Kota Manado yang paling banyak terdapat di Kecamatan Mapanget. Hal itu dikarenakan Kecamatan Mapanget memiliki topografi yang relatif rata sehingga dapat mengurangi biaya pematangan lahan yang akan dilakukan oleh developer perumahan, jaringan jalan seperti Jalan Manado By Pass yang melewati Kecamatan Mapanget, selain itu keberadaan Bandara Sam Ratulangi yang menjadi pintu gerbang Sulawesi Utara menyebabkan masyarakat merasa dekat dengan akses untuk menuju keluar daerah. Pada saat ini di Kecamatan Mapanget telah banyak dibangun pusat-pusat perbelanjaan yang menjadi magnet bagi masyarakat untuk datang dan berdomisili di kecamatan ini, seperti Hypermart Kairagi, Mall Grand Kawanua, Super Market Paniki Jaya, Simple Mart, Indo Grosir, dan Trans Mart.
Pembangunan perumahan di Kota Manado juga seiring dengan rencana pemerintah dalam rangka pembangunan Kota Baru Manado yang terletak di Kecamatan Mapanget dan juga menurut Peta Pola Ruang di dalam Rencana Tata Ruang Wilayah Kota Manado sebagian besar wilayah Kecamatan Mapanget peruntukannya adalah perumahan.

Tabel 1. Banyaknya Penduduk Menurut Kecamatan

\begin{tabular}{lcccc}
\hline Kecamatan & \multicolumn{2}{c}{$\mathbf{2 0 1 3}$} & \multicolumn{2}{c}{$\mathbf{2 0 1 4}$} \\
\hline & $\begin{array}{c}\text { Laki- } \\
\text { laki }\end{array}$ & Perempuan & $\begin{array}{c}\text { Laki- } \\
\text { laki }\end{array}$ & Perempuan \\
\hline Malalayang & 28.467 & 28.473 & 28.17 & 28.629 \\
Sario & 11.481 & 11.554 & 12.025 & 12.524 \\
Wanea & 28.088 & 28.636 & 27.869 & 28.344 \\
Wenang & 15.634 & 26.238 & 17.898 & 18.279 \\
Tikala & 14.772 & 14.363 & 14.523 & 14.825 \\
Paal Dua & 21.614 & 21.015 & 20.671 & 21.299 \\
Mapanget & 26.379 & 25.795 & 25.704 & 25.927 \\
Singkil & 23.899 & 23.409 & 24.078 & 23.961 \\
Tuminting & 26.353 & 25.7 & 25.698 & 25.712 \\
Bunaken & 11.094 & 10.849 & 13.439 & 7.538 \\
Bunaken & 2.925 & 2.858 & 3.061 & 3.083 \\
Kepulauan & \multicolumn{4}{|c}{} \\
Manado & 210.706 & 208.89 & 213.136 & 210.121 \\
\hline Sumber : Badan Pusat Statistik Kota Manado
\end{tabular}

Salah satu perumahan yang berdiri di Kecamatan Mapanget adalah Perumahan Griya Paniki Indah. Perumahan Griya Paniki Indah adalah perumahan yang terletak di Jalan Adipura, dan pada saat ini terletak di tiga kelurahan, yaitu Kelurahan Paniki Bawah, Kelurahan Buha, dan Kelurahan Bengkol, yang kesemuanya masuk pada Kecamatan Mapanget. Perumahan Griya Paniki Indah dikembangkan oleh PT. Setia Kawan Lestari dan PT. Bumi Mapanget Asri pada Oktober 2005 dan pada saat ini telah memiliki sekitar 6000 rumah yang menjadikan perumahan ini terbesar di Sulawesi Utara dengan luas 220 Hektar.

Perumahan Griya Paniki Indah memiliki beragam fasilitas yang membuat alasan masyarakat Kota Manado memilih perumahan ini sebagai tempat tinggal maupun sebagai sarana investasi. Fasilitas yang ada antara lain Masjid, Gereja, sarana olah raga, water park, sekolah, dan mempunyai akses menuju jalan Manado By Pass 2. Perumahan ini juga telah mengikuti Peraturan Pemerintah Nomor 14 Tahun 2016 tentang Penyelenggaraan Perumahan dan Kawasan Pemukiman, yang pada inti peraturan tersebut mempertegas kewajiban pengusaha untuk memenuhi hunian berimbang dengan pola 1:2:3, artinya bagi pengembang yang membangun satu unit rumah mewah, harus membangun dua unit rumah 
menengah, serta tiga unit rumah sederhana.

Perumahan Griya Paniki Indah mempunyai beragam luasan kapling bidang tanah dan bangunan :

a. Luas tanah $105 \mathrm{M}^{2}$, luas bangunan $36 \mathrm{M}^{2}$

b. Luas tanah $126 \mathrm{M}^{2}$, luas bangunan $51 \mathrm{M}^{2}$

c. Luas tanah $162 \mathrm{M}^{2}$, luas bangunan $70 \mathrm{M}^{2}$

d. Luas tanah $200 \mathrm{M}^{2}$, luas bangunan $97 \mathrm{M}^{2}$

e. Luas tanah $525 \mathrm{M}^{2}$, luas bangunan $100 \mathrm{M}^{2}$

Pembangunan perumahan di Kota

Manado khususnya Perumahan Griya Paniki Indah yang merupakan perumahan terbesar di Sulawesi Utara memunculkan banyaknya objekobjek pajak yang baru, sehingga potensi pemasukan pajak daerah dari perumahan ini sangat tinggi bagi Kota Manado karena perumahan merupakan jenis properti yang paling dominan dan yang paling sering ditransaksikan.

\section{Penerimaan BPHTB di Kota Manado}

Pembangunan perumahan untuk hunian merupakan salah satu upaya memenuhi kebutuhan dasar bagi penduduk di suatu wilayah. Bahkan dalam konsideran UU No. 1/2011 tentang Perumahan dan Kawasan Permukiman secara tegas disebutkan bahwa negara bertanggung jawab melindungi segenap bangsa Indonesia melalui penyelenggaraan perumahan dan kawasan permukiman agar masyarakat mampu bertempat tinggal serta menghuni rumah yang layak dan terjangkau di dalam perumahan yang sehat, aman, harmonis, dan berkelanjutan di seluruh wilayah Indonesia. Penyelenggaraan perumahan \& kawasan permukiman oleh negara ini mendapatkan dukungan penuh oleh pelaku bisnis properti/pengembang. Persoalannya adalah tugas mulia yang dilakukan oleh pengembang untuk menyediakan perumahan permukiman secara layak dengan harga terjangkau, seringkali tidak dilakukan secara baik dan taat azas. Akibatnya masyarakat konsumen dan pemerintah daerahlah yang dirugikan dalam hal pungutan pajak BPHTB. Berdasarkan Undang-Undang Nomor 28 Tahun 2009 tentang Pajak Daerah dan Retribusi Daerah, salah satu jenis pajak pusat yang dialihkan menjadi pajak daerah adalah BPHTB. Pengalihan BPHTB menjadi pajak daerah diawali dengan perumusan kebijakan yang dituangkan dalam UU Nomor 28 Tahun 2009 tentang Pajak Daerah dan Retribusi Daerah. Dengan ditetapkannya BPHTB menjadi tanggungjawab daerah, dan perlu diatur dan di tetapkan dengan suatu peraturan, yaitu Peraturan Daerah. Pemungutan BPHTB terlaksana mulai tanggal 1
Januari 2011. Dengan adanya pengalihan ini, BPHTB dipercaya sebagai sumber pendapatan asli daerah yang memiliki potensi sangat besar. Dengan ditetapkannya BPHTB menjadi tanggungjawab daerah, mulai dari perumusan kebijakan, pelaksanaan pemungutan, dan pemanfaatan pendapatan BPHTB. Tugas dan tanggungjawab daerah dalam menerima pengalihan BPHTB juga perlu diatur dan ditetapkan dengan suatu peraturan, sehingga setiap daerah terdorong untuk segera mempersiapkan segala sesuatu yang diperlukan untuk pemungutan BPHTB.

Pemerintah Daerah yang bersangkutan harus terlebih dahulu memiliki Peraturan Daerah (Perda) mengenai tata kelola pemungutan BPHTB, karena dalam Perda tersebut yang akan menjadi dasar untuk Pemerintah Daerah dapat melakukan memungut BPHTB terhadap Wajib Pajak. Setiap Pemerintah Daerah diberikan kebebasan untuk mengelola sesuai dengan kemampuannya yang telah diatur dalam Perda tersebut sebagai landasan acuan pemungutan BPHTB. Pemerintah Daerah tentu akan lebih memahami seluk beluk daerahnya serta yang terbaik bagi daerahnya, serta masyarakat perlu adanya sosialisasi sehingga dapat mengerti bahwa di tahun-tahun berikutnya keberagaman sistem dan pola pemungutan BPHTB. Oleh karena itu, salah satu indikator yang dapat digunakan untuk melihat kesiapan daerah memungut BPHTB adalah perkembangan penerbitan BPHTB oleh Kabupaten/Kota dari waktu ke waktu.

Pengolahan Bea Perolehan Hak Atas Tanah dan Bangunan (BPHTB) telah diserahkan KPP Pratama kepada Pemerintah Daerah, termasuk Pemerintah Kota Manado. Per 1 Januari 2011 dikelola Dinas Pendapatan Daerah. Pemerintah Daerah Kota Manado mengeluarkan Peraturan Daerah Kota Manado Nomor 1 tahun 2011 sebagai landasan dalam pemungutan Bea Perolehan Hak atas Tanah dan Bangunan. Dengan adanya pengalihan ini, BPHTB dipercaya sebagai sumber pendapatan asli daerah yang memiliki potensi sangat besar. Dengan ditetapkannya BPHTB menjadi tanggung jawab daerah, mulai dari perumusan kebijakan, pelaksanaan pemungutan, dan pemanfaatan pendapatan BPHTB. Tugas dan tanggungjawab daerah dalam menerima pengalihan BPHTB juga perlu diatur dan ditetapkan dengan suatu peraturan, sehingga setiap daerah terdorong untuk segera mempersiapkan segala sesuatu yang diperlukan untuk pemungutan BPHTB. Instansi 
yang mengelola BPHTB Kota Manado dahulu bernama Dinas Pendapatan Daerah Kota Manado dan sejak tanggal 1 januari 2017 telah berganti nama menjadi Badan Pengelola Pajak dan Retibusi Daerah Kota Manado. Pergantian nama tersebut berdasarkan Peraturan Walikota Manado Nomor 61 Tahun 2016 tentang Kedudukan, Susunan Organisasi, Tugas dan Fungsi Serta Tata Kerja Badan Pengelola Pajak dan Retribusi Daerah Kota Manado Tipe A. Instansi tersebut mempunyai tugas membantu Walikota dalam melaksanakan fungsi penunjang urusan pemerintahan bidang pengelolaan pajak dan retribusi daerah.

\begin{tabular}{lcccc}
\multicolumn{5}{l}{ Tabel 2. Jumlah Penerimaan BPHTB Kota Manado } \\
\hline No & Tahun & Target (Rp) & Realisasi (Rp) & Presentase \\
\hline 1. & 2011 & 42.500 .000 .000 & 30.169 .578 .345 & $70,99 \%$ \\
2. & 2012 & 35.781 .001 .690 & 41.846 .457 .617 & $116,95 \%$ \\
3. & 2013 & 43.500 .000 .000 & 44.836 .858 .810 & $103.07 \%$ \\
4. & 2014 & 45.675 .000 .000 & 38.091 .690 .080 & $83,40 \%$ \\
5. & 2015 & 45.675 .000 .000 & 40.580 .747 .667 & $88,85 \%$ \\
\hline 6. & 2016 & 41.576 & 28.630 .670 .885 & $68,86 \%$ \\
\hline 7. & 2017 & 34.050 .000 .000 & - & - \\
\hline \multicolumn{5}{l}{ Sumber : Badan Pengelola Pajak Dan Retribusi Daerah }
\end{tabular}

Berdasarkan Tabel 2 tersebut di atas bisa dilihat perkembangan pajak Bea Perolehan Hak atas Tanah dan Bangunan di Kota Manado. Perkembangan BPHTB di Kota Manado dari tahun 2011-2015 mengalami fluktuasi pada tahun 2011, yaitu sebesar Rp. 30.169.578.345 tahun 2012 naik menjadi Rp. 41.846.457.614 meningkat menjadi Rp. 44.836.858.810 pada tahun 2013, akan tetapi pada tahun 2014 turun menjadi Rp. 38.091.690.080 dan naik kembali pada tahun 2015 menjadi Rp. 40.580.747.667. Pada tahun 2016 mengalami penurunan yang signifikan yaitu sebesar Rp. 28.630.670.885. Apabila dilihat dari sisi persentase capaian penerimaan BPHTB, jumlah penerimaannya belum dapat mencapai target yang ditentukan, hanya pada tahun 2012 dan 2013 saja yang dapat mencapai target. Namun target pada tahun 2012 tersebut adalah yang paling kecil apabila dibandingkan dengan tahuntahun yang lain. Pada tahun 2016 target penerimaan pajak BPHTB mengalami penurunan, hal ini dikarenakan realisasi penerimaan BPHTB hanya mencapai $68,86 \%$.

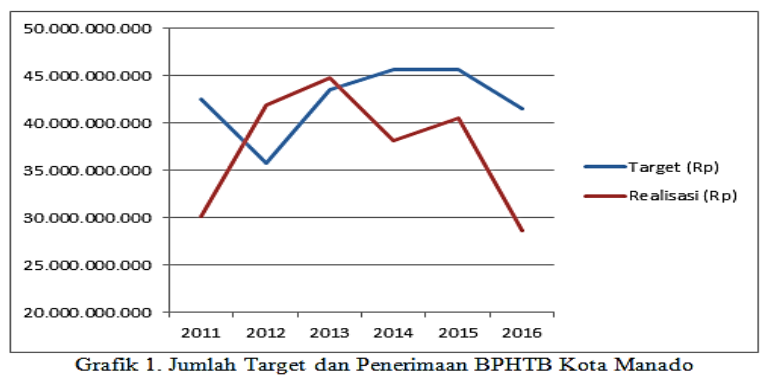

Terlihat jelas sekali bahwa tahun 2016, realisasi penerimaan BPHTB Kota Manado menurun tajam, bahkan mencapai titik terendah dalam kurun waktu 6 tahun terakhir. Secara garis besar, penerimaan BPHTB Kota Manado belum dapat mencapai target yang telah ditentukan. Oleh sebab itu, Peta Zona Nilai Tanah diharapkan menjadi sebuah instrumen dasar dalam pengenaan pajak BPHTB sehingga diharapkan target penerimaan BPHTB Kota Manado dapat tercapai.

\section{Kontribusi BPHTB Terhadap PAD Kota Manado}

Pajak Bea Perolehan atas Tanah dan Bangunan (BPHTB) merupakan bagian dari pajak daerah. Pada mulanya BPHTB dikelola olah pemerintah pusat, mulai 1 januari 2011 pembagian BPHTB sepenuhnya akan menjadi milik pemerintah daerah. Di Kota Manado BPHTB mempunyai peran penting pada peningkatan pendapatan asli daerah. Untuk untuk mengetahui seberapa besar kontribusi Bea Perolehan Hak atas Tanah dan Bangunan terhadap Pendapatan Asli Daerah Kota Manado, dapat menggunakan model perhitungan kontribusi sebagai berikut:

Kontribusi $=\frac{\text { Realisasi Penerimaan } B P T H B}{\text { Realisasi Penerimaan PAD }} \times 100 \%$

Berikut rincian kontibusi penerimaan BPHTB terhadap peningkatan Pendapatan Asli Daerah kota Manado :

Tabel 3. Kontribusi BPHTB terhadap PAD Kota Manado

\begin{tabular}{cccc}
\hline Tahun & $\begin{array}{c}\text { Realisasi } \\
\text { BPHTB (Rp) }\end{array}$ & $\begin{array}{c}\text { Realisasi PAD } \\
(\text { Rp) }\end{array}$ & Presentase \\
\hline 2011 & 30.169 .578 .345 & 174.695 .690 .608 & $17,27 \%$ \\
2012 & 41.846 .457 .614 & 178.307 .223 .000 & $23,47 \%$ \\
2013 & 44.836 .858 .810 & 215.871 .042 .000 & $20,77 \%$ \\
2014 & 38.091 .690 .080 & 263.392 .316 .000 & $14,46 \%$ \\
2015 & 40.580 .747 .667 & 282.525 .557 .000 & $14,36 \%$ \\
2016 & 28.630 .670 .885 & 308.939 .630 .147 & $9,27 \%$ \\
\hline
\end{tabular}

Dari tabel di atas dapat dilihat bahwa BPHTB mempunyai peran dalam peningkatan Pendapatan Asli Daerah (PAD) Kota Manado. Pada tahun 2011, Pendapatan Asli Daerah Kota Manado sebesar Rp 174.695.690.608, ini merupakan total dari sumber Pendapatan Asli Daerah yang dikelola oleh Pemerintah Daerah sebelum berlakunya undang-undang No. 28 tahun 2009 tentang Pajak Daerah dan Retribusi Daerah (PDRD). Pada tahun 2012 sampai dengan tahun 2016, Pendapatan Asli Daerah Kota Manado terus mengalami kenaikan secara bertahap, namun berbanding terbalik dengan jumlah prosentase 
kontribusi BPHTB Kota Manado terhadap Pendapatan Asli Daerah yang justru terus mengalami penurunan sejak tahun 2012 sampai dengan 2016 dan mencapai titik terendahnya pada tahun 2016 yang hanya memberikan kontribusi sebesar 9,27 \%. Apabila kontribusi BPHTB terhadap PAD kota Manado dilihat dalam grafik batang, maka akan menjadi sebagai berikut :

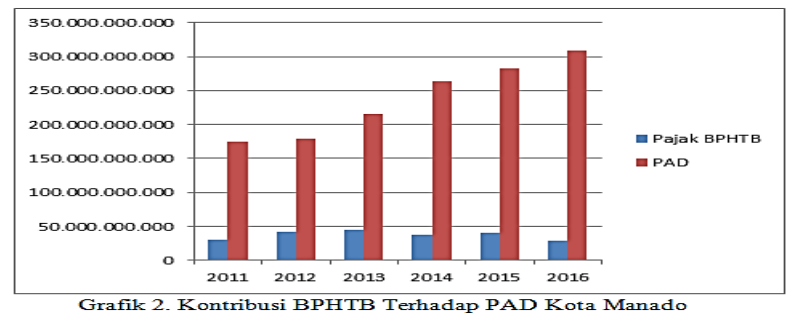

Grafik di atas menunjukkan pajak BPHTB cenderung mengalami penurunan, sebaliknya Pendapatan Asli Daerah terus mengalami peningkatan mulai tahun 2011 sampai dengan 2016.

\section{Pengujian Beda Rata-rata Penerimaan BPHTB Berdasarkan NJOP dengan Peta Zona Nilai Tanah}

Berdasarkan data yang didapatkan di lapangan, dilakukan pengambilan sampel sebanyak 300 bidang tanah yang tersebar pada Perumahan Griya Paniki Indah yang kemudian dapat dilakukan stratifikasi menjadi stratifikasi rumah sederhana, rumah menengah, dan rumah mewah. Nilai harga tanah tertinggi terdapat di Jalan Markisa yang merupakan daerah komersil dan lebih dekat terhadap fasilitas umum seperti supermarket, sarana olah raga, dan water park yang menjadi primadona untuk perumahan ini dan di Jalan Boulevard GPI yang merupakan jalan utama perumahan ini. Sedangkan nilai harga terendah terdapat di daerah rumah sangat sederhana dan mempunyai pola yang sama terhadap harga jual tersebut karena memang penjualan ditujukan kepada masyarakat berpenghasilan rendah. Pengambilan sampel di lapangan dilakukan terhadap jual beli yang dilakukan pada kurun waktu 2014-2015 yang menurut developer Perumahan Griya Paniki Indah tidak terdapat kenaikan harga jual, sehingga yang dijadikan sebagai perbandingan adalah nilai tanah pada Peta Zona Nilai Tanah produk Badan Pertanahan Nasional tahun 2014 maupun 2015. Pengolahan data dilakukan dengan cara mencatat harga transaksi yang dilakukan terhadap objek jual beli. Harga jual beli yang dituangkan dalam
Akta Jual Beli tersebut meliputi penjumlahan dari harga tanah dan harga bangunan, karena yang menjadi dasar perhitungan BPHTB adalah hasil dari nilai perolehan tanah serta bangunannya. Pada Peta Zona Nilai Tanah hanya tercantum nilai tanahnya saja, sehingga untuk menghitung penerimaan BPHTB yang berdasarkan pada Peta Zona Nilai Tanah adalah penjumlahan dari harga tanah pada Peta Zona Nilai Tanah dan harga jual bangunan. Harga jual bangunan yang tercantum dalam NJOP PBB adalah Rp. 823.000,- per meter persegi dan nilai tanah pada Peta Zona Nilai Tanah adalah Rp. 532.000,- per meter persegi untuk zona rumah sederhana dan Rp. 909.000,per meter persegi untuk zona rumah menengah dan zona rumah mewah. Jumlah sampel yang diambil peneliti adalah sebanyak 300 buah sampel yang tersebar di seluruh Perumahan Griya Paniki Indah. Sampel tersebut diambil secara merata agar mendapatkan stratifikasi nilai tanah sehingga dapat dibuat menjadi :

- Stratifikasi rumah sederhana (150 sampel), terdapat di Jalan Anggrek, Jalan Gandaria, Jalan Lengkeng, Jalan Apel, Jalan Ceri, Jalan Flamboyan.

- Stratifikasi rumah menengah (100 sampel), terdapat di Jalan Delima, Jalan Bougenville, Jalan Mawar, Jalan Anggur

- Stratifikasi rumah mewah (50 sampel), terdapat di Jalan Boulevard GPI, Jalan Markisa, Jalan Akasia.

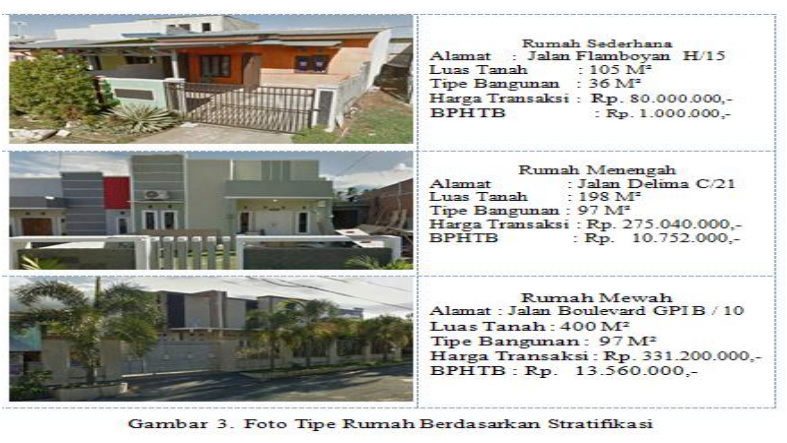

Cara perhitungan yang digunakan dalam mencari hasil penerimaan BPHTB berdasarkan NJOP dari 300 sampel adalah dengan rumus : BPHTB $=5 \% \times$ (NPOP-NPOPTKP) Sebagai contoh untuk sampel yang terletak di Jalan Flamboyan H / 15 seluas $105 \mathrm{~m}^{2}$ (rumah sederhana), dengan harga transaksi sebesar Rp. 80.000.000 meliputi tanah dan bangunannya :

$\mathrm{BPHTB}=5 \% \times(80.000 .000-60.000 .000)$

$$
\begin{aligned}
& =5 \% \times 20.000 .000 \\
& =1.000 .000
\end{aligned}
$$


Hasil perhitungan BPHTB berdasarkan NJOP untuk sampel di Jalan Flamboyan H / 15 adalah sebesar Rp. 1.000.000. Perhitungan BPTHB berdasarkan Peta Zona Nilai Tanah, terlebih dahulu harus diketahui nilai bangunan dari sampel tersebut dengan cara mengalikan luas bangunan dengan NJOP bangunan per meter persegi. Hal ini dikarenakan di dalam Peta Zona Nilai Tanah hanya memuat nilai tanahnya saja, sedangkan untuk mencari BPHTB adalah penjumlahan dari tanah dan bangunan.

Sebagai contoh untuk sampel yang terletak di Jalan Flamboyan H / 15 seluas $105 \mathrm{~m}^{2}$ (rumah sederhana), nilai tanah dalam ZNT sebesar Rp. 532.000 per meter, bangunan seluas $36 \mathrm{~m}^{2}$ dengan harga per meter bangunan adalah Rp. 823.000 .

$$
\begin{aligned}
\text { Nilai tanah keseluruhan } & =532.000 \times 105 \mathrm{~m}^{2} \\
& =55.860 .000
\end{aligned}
$$

Nilai bangunan keseluruhan $=823.000 \times 36 \mathrm{~m}^{2}$

$$
=29.628 .000
$$

Nilai NPOP $=55.860 .000+29.628 .000$

$$
=85.488 .000
$$

Perhitungan BPHTB berdasarkan Peta ZNT :

$\mathrm{BPHTB}=5 \% \times(85.488 .000-60.000 .000)$

$$
\begin{aligned}
& =5 \% \times 25.488 .000 \\
& =1.274 .400
\end{aligned}
$$

Hasil perhitungan BPHTB berdasarkan Peta ZNT untuk sampel di Jalan Flamboyan H / 15 adalah sebesar Rp. 1.274.400. Berdasarkan uraian tersebut, selisih perbandingan jumlah BPHTB antara NJOP dengan ZNT adalah Rp. 274.400. Rata-rata jumlah penerimaan BPHTB yang mengacu pada NJOP PBB atau harga transaksi pada 300 sampel yaitu Rp. 4.000.915, sedangkan rata-rata jumlah penerimaan BPHTB 300 sampel yang didasarkan pada Peta Zona Nilai Tanah yaitu Rp. 5.435.543. Sehingga untuk ratarata selisih kedua perhitungan 300 sampel tersebut adalah Rp. 1.434.629 untuk setiap bidang tanahnya. Setelah dilakukan perhitungan secara keseluruhan terhadap hasil penelitian, jumlah penerimaan BPHTB yang mengacu pada NJOP PBB atau harga transaksi pada 300 sampel yaitu Rp.1.200.274.450 dengan rincian Rp. 186.446.000 untuk stratifikasi rumah sederhana, Rp. 499.876.950 untuk stratifikasi rumah menengah, dan Rp. 513.951.500 untuk stratifikasi rumah mewah. Nilai perolehan BPHTB yang didasarkan pada nilai harga tanah yang tertera pada Peta Zona Nilai Tanah menunjukkan peningkatan sebesar Rp. 1.630.663.000 dengan rincian Rp. 219.888.000 untuk stratifikasi rumah sederhana, Rp. 693.815.650 untuk stratifikasi rumah menengah, dan Rp. 716.959.350 untuk stratifikasi rumah mewah. Selisih antara perbandingan keduanya adalah senilai Rp. 430.388.550, dengan rincian Rp. 33.442.000 untuk rumah sederhana, $\mathrm{Rp}$. 193.938.700 untuk rumah menengah, dan $\mathrm{Rp}$. 203.007.850 untuk rumah mewah. Potensi peningkatan penerimaan BPHTB dengan berdasarkan Peta Zona Nilai Tanah adalah sebesar $35,86 \%$ dengan perbandingan antara NJOP berbanding ZNT adalah $1: 1,36$

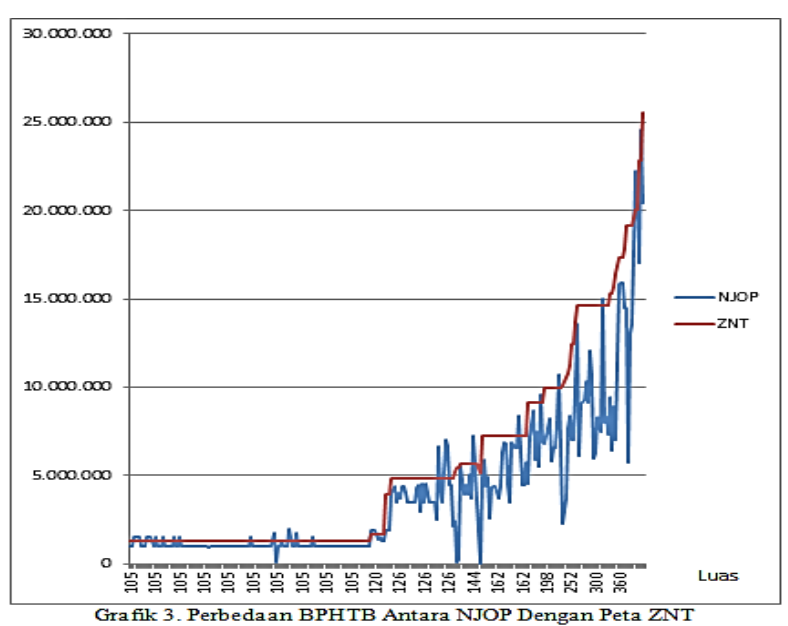

Berdasarkan grafik di atas terlihat perbedaan yang signifikan antara jumlah penerimaan BPHTB berdasarkan NJOP PBB dengan berdasarkan Peta ZNT. BPHTB dengan menggunakan NJOP PBB terlihat grafik yang lebih fluktuatif dan menandakan bahwa pengenaan BPHTB berdasarkan NJOP PBB masih menimbulkan keberagaman dalam penentuan besarnya BPHTB. Sedangkan penerimaan BPHTB berdasarkan Peta ZNT dapat disimpulkan dari grafik di atas, rata-rata jumlah penerimaan BPHTB berdasarkan Peta ZNT lebih di atas atau lebih besar dibandingkan NJOP. Hasil Pengujian Hipotesis menunjukkan terdapat perbedaan jumlah penerimaan BPHTB antara BPHTB berdasarkan NJOP PBB dengan Peta Zona Nilai Tanah. Hal tersebut didukung juga oleh uji $t$ dengan nilai $t_{\text {hitung }}(3,629)$ lebih besar dari $t_{\text {tabel }}$ $(1,984)$. Dari hasil tersebut, maka keputusan hasil uji hipotesis adalah Ho ditolak. Sehingga disimpulkan bahwa Peta Zona Nilai Tanah dapat meningkatkan jumlah penerimaan BPHTB di Kota Manado. Dengan kata lain bahwa pengenaan BPHTB dengan menggunakan Peta Zona Nilai Tanah adalah lebih besar jika dibandingkan dengan menggunakan NJOP 
PBB. Dillihat dari hasil penjumlahan BPHTB terhadap keduanya, menunjukkan selisih sebesar Rp. 430.388.550,- sehingga potensi yang dapat ditingkatkan adalah sebesar 35,86 $\%$. Berdasarkan grafik di atas terlihat perbedaan yang signifikan antara jumlah penerimaan BPHTB berdasarkan NJOP PBB dengan berdasarkan Peta ZNT. BPHTB dengan menggunakan NJOP PBB terlihat grafik yang lebih fluktuatif dan menandakan bahwa pengenaan BPHTB berdasarkan NJOP PBB masih menimbulkan keberagaman dalam penentuan besarnya BPHTB. Sedangkan penerimaan BPHTB berdasarkan Peta ZNT dapat disimpulkan dari grafik di atas, rata-rata jumlah penerimaan BPHTB berdasarkan Peta ZNT lebih di atas atau lebih besar dibandingkan NJOP. Hasil Pengujian Hipotesis menunjukkan terdapat perbedaan jumlah penerimaan BPHTB antara BPHTB berdasarkan NJOP PBB dengan Peta Zona Nilai Tanah. Hal tersebut didukung juga oleh uji $t$ dengan nilai $t_{\text {hitung }}(3,629)$ lebih besar dari $t_{\text {tabel }}(1,984)$. Dari hasil tersebut, maka keputusan hasil uji hipotesis adalah Ho ditolak. Sehingga disimpulkan bahwa Peta Zona Nilai Tanah dapat meningkatkan jumlah penerimaan BPHTB di Kota Manado. Dengan kata lain bahwa pengenaan BPHTB dengan menggunakan Peta Zona Nilai Tanah adalah lebih besar jika dibandingkan dengan menggunakan NJOP PBB. Dillihat dari hasil penjumlahan BPHTB terhadap keduanya, menunjukkan selisih sebesar Rp. 430.388.550,sehingga potensi yang dapat ditingkatkan adalah sebesar $35,86 \%$.

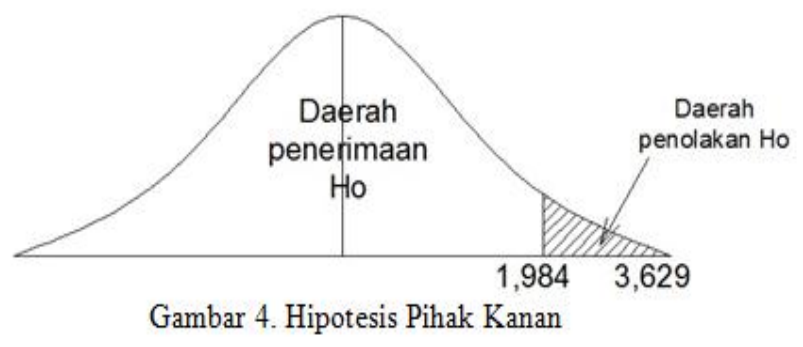

\section{Tantangan Dalam Pelaksanaan Peta Zona Nilai Tanah Di Kota Manado}

Menurut peneliti, bahwa yang menjadi tantangan dalam menghadapi kendala dan hambatan pelaksanaan Peta Zona Nilai Tanah sebagai acuan dalam pengenaan pajak BPHTB di Kota Manado adalah :
1. Belum tercipta sinergi dengan pihak-pihak yang terkait dalam hal pemungutan BPHTB yaitu Badan Pertanahan Nasional Kota Manado, Pemerintah Kota Manado yang dalam hal ini Badan Pengelola Pajak dan Retribusi Daerah Kota Manado, serta Notaris/PPAT .

2. Kurangnya pengetahuan masyarakat tentang adanya pajak BPHTB dalam hal yang menjadi dasar pengenaan BPHTB, tata cara penghitungan BPHTB, maupun mekanisme pembayaran BPHTB.

3. Adanya keberatan dari masyarakat apabila jumlah BPHTB yang harus dibayarkan menjadi lebih tinggi.

4. Adanya kecenderungan dari sebagian Notaris/PPAT yang sengaja menurunkan nilai transaksi yang tercantum dalam Akta Jual Beli, sehingga timbul kesan melalui Notaris/PPAT si "A" lebih murah dengan tujuan agar lebih banyak masyarakat menggunakan jasanya sebagai Notaris/PPAT.

5. Beberapa wajib pajak di Kota Manado masih kurang kesadarannya dalam mentaati penyetoran pajak sesuai dengan aturan, atau juga ada yang yang terkesan pura-pura lupa dengan kewajibannya.

\section{KESIMPULAN DAN SARAN}

\section{Kesimpulan}

Berdasarkan hasil dan pembahasan yang diuraikan pada bab sebelumnya, maka dapat disimpulkan sebagai berikut :

1. Jumlah penerimaan BPHTB yang mengacu pada NJOP PBB atau harga transaksi pada 300 sampel pada Perumahan Griya Paniki Indah yaitu sebesar Rp. 1.200.274.450, sedangkan jumlah penerimaan BPHTB yang mengacu pada Peta Zona Nilai Tanah sebesar Rp. 1.630.663.000 dengan perbandingan antara NJOP berbanding ZNT adalah $1: 1,36$

2. Terhadap perbedaan tersebut, maka potensi peningkatan BPHTB berdasarkan Peta Zona Nilai Tanah pada Perumahan Griya Paniki Indah adalah sebesar $35,86 \%$. 


\section{Saran}

1. Diperlukan keseriusan, koordinasi, dan kerjasama antar instansi terkait agar penggunaan Peta Zona Nilai Tanah di Kota Manado dapat terlaksana dengan baik sehingga jumlah penerimaan BPHTB berperan besar dalam peningkatan PAD.

2. Perlu dilakukan sosialisasi yang berkesinambungan kepada masyarakat, agar disaat ada kebijakan baru yang dibuat pemerintah Kota Manado untuk penerapan Peta Zona Nilai Tanah bisa diketahui oleh masyarakat.

3. Mengingat pentingnya informasi mengenai harga tanah, dalam pembuatan Peta ZNT penilaian tanah bukan hanya cukup berdasarkan wilayah saja tetapi harus memperhatikan lokasi ataupun posisi dari suatu obyek pajak, dan harus terus dilakukan perbaikan dan penyempurnaan terhadap peta ZNT produk BPN. Peta ZNT yang dibuat sebaiknya berbasis persil dan betul-betul menunjukkan nilai tanah yang sebenarnya.

4. Penerapan Peta ZNT perlu dibarengi dengan penerapan kebijakan insentif dan disinsentif dalam penetapan pajak untuk mengurangi keberatan dari masyarakat sehingga pemungutan Bea Perolehan Hak atas Tanah dapat ditarik dari masyarakat dengan tidak mengganggu rasa keadilan terhadap masyarakat.

5. Melakukan inovasi pada Kantor Pertanahan melalui situs Kantor Pertanahan Kota Manado yang bisa diakses oleh masyarakat melalui alamat www.kot-manado.go.id dengan menampilkan Peta Zona Nilai Tanah yang berbasis peta citra satelit, sehingga masyarakat dapat mengetahui langsung lokasi tanah mereka. sehingga masyarakat dapat dengan mudah melihat harga zona nilai tanah permeter.

\section{DAFTAR PUSTAKA}

Ariyanti, Sri, 2006, "Pemungutan Bea Perolehan Hak Atas Tanah Dan Bangunan (BPHTB) Dalam Jual Beli Tanah Dan Atau Bangunan Di Kota Semarang", Undip, Semarang.
Al Rashid, Harun, 1987, Sekilas Tentang Jual Beli Tanah (Berikut Peraturanperaturannya), Ghalia Indonesia, Jakarta.

Adrian, Sutedi, 2008, Hukum Pajak dan Retribusi Daerah, Ghalia Indonesia, Bogor.

Budi, Rizki., Kahar, Sutomo., Subiyanto, Sawitri. 2014. Pembuatan Peta Zona Nilai Tanah Dengan Pendekatan Penilaian Massal Untuk Meningkatkan Potensi PAD (Pendapatan Asli Daerah) Khususnya PBB Dan BPHTB, Undergraduate thesis Program Studi Teknik Geodesi Fakultas Teknik, Unversitas Diponegoro.

Darwin, 2013, Pajak Bumi dan Bangunan Dalam Tataran Praktis Edisi 2, Penerbit Wacana Media, Jakarta.

Halim, Abdul, 2004. Akuntansi Keuangan Daerah. Penerbit UPP AMP YKPN. Yogyakarta.

Harsono, Budi, 2007, Hukum Agraria Indonesia, Djambatan, Jakarta.

Hartoyo, Harry dan Untung Supardi, 2010, Membedah Pengelolaan Administrasi $P B B$ dan BPHTB : Pengalaman di Pemerintah Pusat Referensi Untuk Implementasi Pajak Daerah, Penerbit Mitra Wacana Media, Jakarta.

Heranda, Ibnu Adhi. 2015. Pemetaan Zona Nilai Tanah Untuk Menentukan Nilai Jual Objek Pajak (NJOP) Menggunakan Sistem Informasi Geografis. Jurnal Geodesi Undip. Program Studi Teknik Geodesi, Fakultas Teknik, Universitas Diponegoro.

Insukindro, 1994, Penerimaan Pajak. Djambatan. Bandung.

Jeddawi, Murtir, 2008, Implementasi Kebijakan Otonomi Daerah (Analisis Kewenangan, Kelembagaan,managemen Kepegawaian, dan Peraturan Daerah), Total Media, Yogyakarta.

Junianto, B., dan Haryanto, A. T, 2015, Pemerintah Akan Ganti NJOP dengan Zona Nilai Tanah, http:// nasional. news. viva.co.id/news/read/584949-pemerintahakan-ganti-njop-dengan-zona-nilaitanah. Diunduh pada 24 September 2017 
Kadjatmiko, 2002. Dinamika Sumber Keuangan bagi Daerah dalam Rangka Otonomi Daerah, Prosiding Workshop Internasional Implementasi Desentralisasi Fiskal sebagai Upaya Memberdayakan Daerah dalam Membiayai Pembangunan Daerah, Fakultas Ilmu Sosial dan Ilmu Politik Universutas Katolik Parahyangan, Bandung.

Laoh, Esry, 2008, Buku Ajar Ekonomi Pembangunan, Fakultas Pertanian, Universitas Sam Ratulangi, Manado

Mardiasmo, 2011. Perpajakan, Edisi Revisi, Penerbit Andi, Jogjakarta.

Pahala, Maribot dan Siahaan, 2002, Bea perolehan Hak atas Tanah dan Bangunan Teori dan Praktek, Raja Grafindo Persada, Jakarta.

Prihartanto, 2011, Peta ZNT Manfaat Keakuratan Peta Zona Nilai Tanah, http://mazprie82.blogspot.co.id/2011/12/ manfaat-keakuratan-peta-zona-

nilai.html. (diakses tanggal 6 September 2017)

Pudiatmoko, Sri Y, 2002, Pengantar Hukum Pajak, Penerbit Andi offset, Yogyakarta.

Republik Indonesia, 1997, Undang-Undang Nomor 21 Tahun 1997 Tentang Bea Perolehan Hak Atas Tanah Dan Bangunan (Lembaran Negara Republik Indonesia Tahun 1997 Nomor 3688).

Republik Indonesia, 2000, Undang-Undang Nomor 20 Tahun 2000 tentang Perubahan Atas Undang-Undang Nomor 21 Tahun 1997 Tentang Bea Perolehan Hak Atas Tanah Dan bangunan (Tambahan Lembaran negara Republik Indonesia Nomor 9)

Republik Indonesia, 2009, Undang-Undang Nomor 28 Tahun 2009 tentang Pajak Daerah dan Retribusi Daerah (Tambahan Lembaran Negara Republik Indonesia Nomor 5049).

Saragih, Juli Panglima, 2003, Desentralisasi Fiskal dan Keuangan Daerah Dalam Otonomi, Cetakan Pertama, Ghalia Indonesia, Jakarta.
Siahaan, Marihot P, 2005, Pajak Daerah dan Retribusi Daerah, Raja Grafindo Persada, Jakarta.

Simanjuntak, Timbul Hamonangan dan Imam Mukhlis, 2012, Dimensi Ekonomi Perpajakan Dalam Pembangunan Ekonomi, Penerbit Raih Asa Sukses, Depok.

Soemitro, Rochmat, 1989, Pajak Bumi dan Bangunan. PT. Eresco, Bandung.

Soemitro, Rochmat, 1989, Pajak Bumi dan Bangunan. PT. Eresco, Bandung.

Subiyanto, Sawitri. 2015. Analisis Potensi Peningkatan Nilai Jual Objek Pajak (NJOP) Berdasarkan Peta Zona Nilai Tanah (ZNT) (Studi Kasus : Kec. Sidomukti, Kota Salatiga). Jurnal Geodesi Undip. Program Studi Teknik Geodesi. Fakultas Teknik Universitas Diponegoro.

Sugiyono, 2010, Metode Penelitian Kuantitatif Kualitatif dan $R \& D$, PT. Alfabeta, Bandung.

Sumardjono Maria S.W, 2002, Kebijakan Pertanahan Antara Regulasi \& Implementasi, PT. Kompas Media Nusantara, Jakarta.

Supramono, dan Damayanti, 2010, Perpajakan Indonesia, Mekanisme dan Perhitungan, CV. Andi, Yogyakarta

Sumardjono Maria S.W, 2002, Kebijakan Pertanahan Antara Regulasi \& Implementasi, PT. Kompas Media Nusantara, Jakarta.

Suroso, Ismuhadi, 1999, Pendaftaran Tanah Di Indonesia, PT Relindo Jayatama, Jakarta.

Suratman, dan Philips Dillah, 2012, Metode Penelitian Hukum, Alfabeta, Bandung.

Sutaryono, 2013, Problematika Zona Nilai Tanah, http:// manajemenpertanahan. blogspot.co.id/2013/01/problematikazona-nilai-tanah.html(diakses tanggal 6 September 2017)

Sutawijaya, A, 2004, Analisis Faktor-Faktor Yang Mempengaruhi Nilai Tanah Sebagai Dasar Penilaian Nilai Jual Objek Pajak (NJOP) PBB di Kota Semarang. Jurnal Ekonomi Pembangunan, Vol. 9, No. 1, Juni 2004, 69. Universitas Islam Indonesia. Semarang. 
Wahjono, Padmo, 1984, Undang-undang Perpajakan Beserta Penjelasan dan Peraturan Pelaksanaan, Ghalia Indonesia, Jakarta

Wahyudi, Eddhi, 2015, Bea Perolehan Hak Atas Tanah dan Bangunan (BPHTB), https:// eddiwahyudi.com/perspektif.pajak-sebagaisarana-pendukung pembangunan//beaperolehan-hak atas-tanah-dan-bangunanbphtb (diakses tanggal 6 September 2017)

Walikota Manado, 2011, Peraturan Daerah Kota Manado Nomor 1 Tahun 2011 tentang Bea Perolehan Hak Atas Tanah dan Bangunan.

Waluyo, Bambang, 1991, Penelitian Hukum Dalam Praktek, Sinar Grafika, Jakarta.
Widhyarsi, Dyah Purworini, 2008, "Pelaksanaan Pemungutan Bea Perolehan Hak Atas Tanah Dan Bangunan (BPHTB) Atas Hibah Wasiat Di Jakarta Barat", Universitas Diponegoro, Semarang. Widyaningsih, Aristanti,2011. Hukum Pajak dan Perpajakan, Penerbit Alfabeta, Bandung

Windy, 2015. Analisis Dasar Pengenaan Dan Kontribusi Bea Perolehan Hak Atas Tanah Dan Bangunan Terhadap Pendapatan Asli Daerah Kota Ternate. Jurnal ISSN2303-1174. Fakultas Ekonomi dan Bisnis, Jurusan Akutansi Universitas Sam Ratulangi Manado. 